\section{References}

${ }^{1}$ Dacie, J V, in The Haemolytic Anaemias, part IV. London, Churchill, 1967.

2 Dausset, J, and Contu, L, Annual Review of Medicine, 1967, 18, 55.

3 Beutler, E, Pharmacological Review, 1969, 21, 73.

4 Chan, T K, Todd, D, and Wong, C C, British Medical fournal, 1964, 2, 102.

${ }^{5}$ Chan, T K, Todd, D, and Wong, C C, fournal of Laboratory and Clinical Medicine, 1965, 66, 937.

${ }^{6}$ Chan, T K, and Todd, D, British Medical fournal, 1975, 1, 131.

' Chan, T K, and Todd, D, American fournal of Human Genetics, 1972, 24, 475.

${ }^{8}$ Tso, S C, British fournal of Haematology, 1972, 23, 621.

${ }^{9}$ Chan, T K, and McFadzean, A J S, Transactions of the Royal Society of Tropical Medicine and Hygiene, 1974, 68, 61.
${ }^{10}$ Dacie, J V, and Lewis, S M, in Practical Haematology, 4th edn. Edinburgh, Churchill Livingstone, 1968.

${ }^{11}$ Chan, T K, et al, Fournal of Laboratory and Clinical Medicine, 1971, 77, 177.

12 Bernini, L, et al, British fournal of Haematology, 1964, 10, 171.

${ }^{13}$ Brewer, G J, et al, fournal of Laboratory and Clinical Medicine, 1961, 58, 217.

14 World Health Organisation, Treatment of Haemoglobinopathies, Technical Report Series, No 509, p 61. Geneva, WHO, 1972.

${ }^{15}$ McFadzean, A J S, and Choa, G H, British Medical fournal, 1953, 2, 360.

${ }_{16}$ Gaetani, et al, Experientia, 1970, 26, 785.

17 Beutler, E, Blood, 1970, 36, 523.

18 Yoshida, A, Science, 1973, 179, 532.

19 Beutler, E, Blood, 1959, 14, 103.

${ }^{20}$ McCaffrey, R P, et al, Annals of Internal Medicine, 1971, 74, 722.

\title{
Reduced respiratory responses to carbon dioxide after propranolol: a central action?
}

\author{
C P MUSTCHIN, H R GRIBBIN, A E TATTERSFIELD, C F GEORGE
}

British Medical fournal, 1976, 2, 1229-1231

\section{Summary}

In a double-blind study in six subjects propranolol significantly reduced the respiratory sensitivity to carbon dioxide rebreathing. This effect seems to have been due to beta-adrenergic blockade, since it was not seen with D-propranolol. In two subjects increasing doses of propranolol caused progressive reductions in respiratory sensitivity to values below normal and similar to those of patients with ventilatory failure. These changes are probably due to a central action of propranolol.

\section{Introduction}

Beta-adrenergic blocking drugs may have deleterious effects in asthmatic patients owing to blockade of endogenous sympathetic drive to bronchial smooth muscle. ${ }^{1-3}$ In contrast, stimulation of beta-adrenergic receptors relaxes bronchial smooth muscle and also stimulates ventilation. ${ }^{4-7}$ During recent studies of the effects of propranolol on exercise we noticed a decrease in the ventilatory response in normal subjects. We therefore examined the effect of propranolol on the response to carbon dioxide rebreathing as this correlates well with the ventilatory response to exercise ${ }^{8}$ but is easier to measure.

We measured both the ventilatory and the maximum rate of inspiratory pressure development $\left(\mathrm{dP} / \mathrm{dt}_{\max }\right)$ responses to hypercapnia. ${ }^{9}$ The latter measurement is a function of the initial contraction of the respiratory muscles and occurs before any significant flow of gas begins. It may, therefore, be regarded as a reflection of output from the "respiratory centre" and may be a more accurate index of the drive to breathe than measurements of ventilation alone. If the lungs are mechanically abnormal simple measurements of ventilation may underestimate the drive

Southampton University Hospitals, Southampton

C P MUSTCHIN, MB, MRCP, research fellow

H R GRIBBIN, MB, MRCP, research fellow

A E TATTERSFIELD, MD, MRCP, senior lecturer in medicine

C F GEORGE, MD, MRCP, professor of clinical pharmacology to breathe because of inefficient conversion of respiratory work into ventilation. Writers have disagreed about the effects of propranolol on airway resistance in normal subjects, ${ }^{10-14}$ but if airway resistance were to rise ventilation might fall as a consequence and give a false impression of respiratory responsiveness to $\mathrm{CO}_{2}$ stimulation.

To separate the beta-adrenergic blocking properties of propranolol from its other actions we examined the effects of both the commercially available racemic mixture (DLpropranolol) and the dextrorotatory isomer (D-propranolol). The latter has only $1 / 60$ th of the beta-adrenergic blocking function of the racemic mixture ${ }^{15}$ but has similar membrane-stabilising activity.

\section{Patients and methods}

Six healthy volunteers aged 22-35 took part. None were receiving regular medication nor was there any previous history of asthma.

Carbon dioxide rebreathing was performed according to the method of Read $^{16}$ as modified by Matthews and Howell. ${ }^{9}$ Progressive hypercapnia was produced by rebreathing mixtures of $5 \% \mathrm{CO}_{2}$ in oxygen. Ventilation was determined by displacing air from a bag in bottle arrangement. A manometer line placed at the mouth was used to detect pressure changes and the signal was electronically differentiated to give $\mathrm{dP} / \mathrm{dt}_{\max }$ for each breath. End tidal $\mathrm{CO}_{2}$ levels were recorded throughout using a Godart Capnograph and were allowed to increase up to values of $9-10 \%$.

Regressions of ventilatory and $\mathrm{dP} / \mathrm{dt}_{\max }$ responses on end tidal $\mathrm{PCO}_{2}$ were calculated by the method of least squares. All were highly linear at high $\mathrm{CO}_{2}$ levels $(\mathrm{r}>0 \cdot 9)$. The slope of the lines was taken as a measure of sensitivity to $\mathrm{CO}_{2}$. The slopes and $\mathrm{x}$-intercept values of the extrapolated line were compared by Wilcoxon's signed-ranks test for paired data.

Spirometry was performed before and after drug administration.

\section{FIRST STUDY}

The effects of DL-propranolol $(80 \mathrm{mg}$ ) and an identical placebo were compared in a double-blind study. The $\mathrm{CO}_{2}$ responses were determined on separate days, two hours after oral administration of the tablets in the fasting state. On another occasion two of the subjects had repeated doses of propranolol $(40,40$, and $80 \mathrm{mg}$ ) every two hours to establish a dose-response relation. Venous blood samples were taken after each series of respiratory response measurements and plasma concentrations were estimated fluorometrically using the method of Shand et al. ${ }^{17}$ 
SECOND STUDY

The effect of $\mathrm{D}$-propranolol $(100 \mathrm{mg}$ ) was investigated in an open study. Responses were measured before and two hours after drug administration.

\section{Results}

DL-Propranolol significantly reduced the ventilatory response to carbon dioxide (see figure and table I): the mean reduction in the slope of the regression was $46.6 \%(\mathrm{P}<0.05)$. The intercept values were not significantly changed. Subjects who showed the greatest initial response to inhaled $\mathrm{CO}_{2}$ showed the greatest reduction after propranolol $(r=0.84 ; P<0.01)$. Similar statistically significant changes

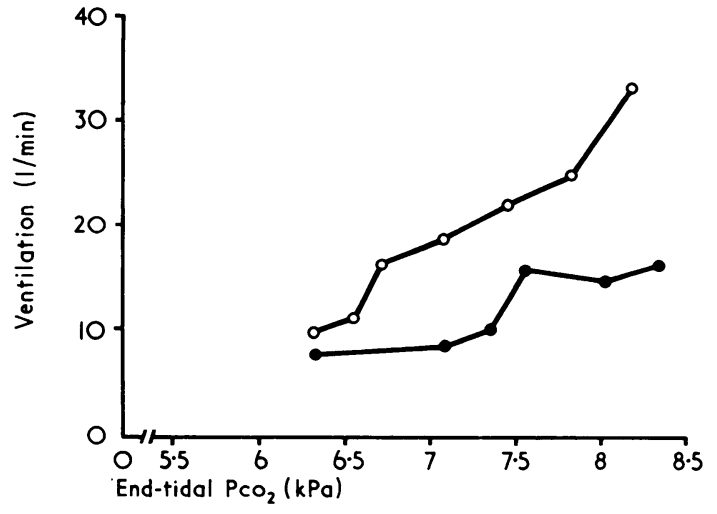

Ventilatory response to $\mathrm{CO}_{2}$ before (open symbols) and after (closed symbols) propranolol in subject No 5 .

TABLE I-Effects of racemic (DL) propranolol on $\mathrm{CO}_{2}$ response (first study)

\begin{tabular}{|c|c|c|c|c|}
\hline Subject No & Control & DL-Propranolol & Control & DL-Propranolol \\
\hline \multicolumn{5}{|c|}{ Ventilation } \\
\hline & \multicolumn{2}{|c|}{$\begin{array}{l}\text { Slope of response } \\
(1 / \mathrm{min} / \mathrm{kPa})\end{array}$} & \multicolumn{2}{|c|}{$\underset{(\mathrm{kPa})}{\mathrm{x} \text {-Intercept value }}$} \\
\hline $\begin{array}{l}1 \\
2 \\
3 \\
4 \\
5 \\
6\end{array}$ & $\begin{array}{c}31 \cdot 75 \\
9 \cdot 68 \\
18 \cdot 80 \\
42 \cdot 63 \\
26 \cdot 94 \\
27 \cdot 40\end{array}$ & $\begin{array}{r}24.13 \\
4.78 \\
11.38 \\
14.44 \\
9.05 \\
20.09\end{array}$ & $\begin{array}{l}6.29 \\
0.30 \\
6.45 \\
5.95 \\
6.08 \\
5.92\end{array}$ & $\begin{array}{r}6.42 \\
4.15 \\
6.13 \\
5.10 \\
4.81 \\
5.09\end{array}$ \\
\hline Mean & $26 \cdot 20$ & 13.98 & $5 \cdot 17$ & $5 \cdot 28$ \\
\hline \multicolumn{5}{|c|}{$d P / d t_{\max }$} \\
\hline & \multicolumn{2}{|c|}{$\begin{array}{c}\text { Slope of response } \\
(\mathrm{kPa} / \mathbf{s} / \mathbf{k P a})\end{array}$} & \multicolumn{2}{|c|}{$\underset{(\mathrm{kPa})}{\mathrm{x} \text {-Intercept value }}$} \\
\hline $\begin{array}{l}1 \\
2 \\
3 \\
4 \\
5 \\
6\end{array}$ & $\begin{array}{l}2.94 \\
0 \cdot 78 \\
2 \cdot 33 \\
4 \cdot 40 \\
3 \cdot 16 \\
4 \cdot 57\end{array}$ & \begin{tabular}{|l|l|}
1.95 \\
0.45 \\
1.16 \\
0.95 \\
0.74 \\
1.98
\end{tabular} & $\begin{array}{l}6 \cdot 68 \\
1 \cdot 73 \\
6 \cdot 77 \\
5 \cdot 73 \\
6 \cdot 21 \\
6 \cdot 22\end{array}$ & $\begin{array}{r}6.43 \\
1.79 \\
6.13 \\
3.86 \\
4.93 \\
0.36\end{array}$ \\
\hline Mean & 3.03 & $1 \cdot 21$ & $3 \cdot 31$ & $3 \cdot 2$ \\
\hline
\end{tabular}

Conversion: SI to traditional units-1 $\mathrm{kPa} \approx 7.5 \mathrm{~mm} \mathrm{Hg}$.

TABLE II-Dose-response study in two subjects

\begin{tabular}{l|c|c|c}
\hline & $\begin{array}{c}\text { Plasma } \\
\text { propranolol } \\
\text { concentration } \\
(\mathrm{ng} / \mathrm{ml})\end{array}$ & $\begin{array}{c}\text { Slope of } \\
\text { ventilatory } \\
\text { response } \\
(1 / \mathrm{min} / \mathrm{kPa})\end{array}$ & $\begin{array}{c}\text { Slope of } \\
\text { dP/dtmax } \\
\text { response } \\
(\mathbf{k P a} / \mathbf{s} / \mathbf{k P a})\end{array}$ \\
\hline Subject No 2 & 0 & 11.21 & 0.66 \\
Control value & 29 & 8.95 & 0.46 \\
After 1st dose & 34 & 6.10 & 0.60 \\
After 2nd dose & 104 & 3.47 & 0.23 \\
After 3rd dose & 0 & 24.50 & 3.59 \\
Subject No 5 & 64 & 18.98 & 3.00 \\
Control value & 112 & 19.05 & 2.47 \\
After 1st dose & 232 & 8.55 & 0.84 \\
After 2nd dose & & & \\
After 3rd dose & & & \\
\hline
\end{tabular}

were noted in the $\mathrm{dP} / \mathrm{dt}_{\max }$ response $(\mathrm{P}<0.05)$. There was also a dose-related reduction in carbon dioxide sensitivity (table II).

There were no significant changes in the forced expiratory volume in 1 second $\left(\mathrm{FEV}_{1}\right)$ after propranolol. D-Propranolol had no significant effect on either the ventilatory or $\mathrm{dP} / \mathrm{dt}_{\max }$ response to $\mathrm{CO}_{2}$ (table III).

TABLE III-Effects of D-propranolol on $\mathrm{CO}_{2}$ response (second study)

\begin{tabular}{|c|c|c|c|c|}
\hline Subject No & Control & DL-Propranolol & Control & DL-Propranolol \\
\hline \multicolumn{5}{|c|}{ Ventilation } \\
\hline & \multicolumn{2}{|c|}{$\begin{array}{c}\text { Slope of response } \\
(1 / \mathrm{min} / \mathrm{kPa})\end{array}$} & \multicolumn{2}{|c|}{$\underset{(\mathrm{kPa})}{\mathrm{x} \text {-Intercept value }}$} \\
\hline $\begin{array}{l}1 \\
2 \\
3 \\
4 \\
5 \\
6\end{array}$ & $\begin{array}{l}32 \cdot 81 \\
11 \cdot 27 \\
19 \cdot 38 \\
43 \cdot 40 \\
25 \cdot 22 \\
31 \cdot 74\end{array}$ & $\begin{array}{r}31 \cdot 17 \\
13.52 \\
22.50 \\
46 \cdot 20 \\
17.98 \\
38.73\end{array}$ & $\begin{array}{l}6 \cdot 13 \\
4 \cdot 57 \\
6 \cdot 08 \\
6 \cdot 15 \\
6 \cdot 56 \\
5 \cdot 49\end{array}$ & $\begin{array}{l}6.27 \\
5.23 \\
6.27 \\
6.04 \\
5.48 \\
5.80\end{array}$ \\
\hline \multirow[t]{2}{*}{ Mean } & $27 \cdot 30$ & $28 \cdot 35$ & $5 \cdot 83$ & $5 \cdot 85$ \\
\hline & \multicolumn{2}{|c|}{$\begin{array}{c}d P / d t_{\max } \\
\text { Slope of response } \\
(\mathrm{kPa} / \mathrm{s} / \mathrm{kPa})\end{array}$} & \multicolumn{2}{|c|}{$\underset{(\mathrm{kPa})}{\mathbf{x} \text {-Intercept value }}$} \\
\hline $\begin{array}{l}1 \\
2 \\
3 \\
4 \\
5 \\
6\end{array}$ & $\begin{array}{l}3.04 \\
0.59 \\
1.64 \\
3.95 \\
3.66 \\
4.56\end{array}$ & $\begin{array}{r}3.40 \\
0.77 \\
2 \cdot 31 \\
5 \cdot 03 \\
3 \cdot 10 \\
4.74\end{array}$ & $\begin{array}{l}6 \cdot 18 \\
4 \cdot 66 \\
6 \cdot 26 \\
6 \cdot 12 \\
6 \cdot 39 \\
5 \cdot 77\end{array}$ & \begin{tabular}{|l|}
6.22 \\
5.13 \\
6.28 \\
6.01 \\
6.16 \\
6.05
\end{tabular} \\
\hline Mean & $2 \cdot 91$ & $3 \cdot 23$ & $5 \cdot 89$ & $5 \cdot 98$ \\
\hline
\end{tabular}

\section{Discussion}

These studies show that propranolol significantly reduces $\mathrm{CO}_{2}$ responsiveness in normal volunteers. In the dose-response study the reduced $\mathrm{CO}_{2}$ responsiveness eventually resembled that seen in bronchitic patients with $\mathrm{CO}_{2}$ insensitivity and retention. ${ }^{18}$ D-Propranolol had no effect, so the observed effects must have been due to beta-blockade.

There are several possible explanations for the observed changes in responsiveness. Significant changes in lung mechanics were unlikely to have occurred as there was no disparity between $\mathrm{dP} / \mathrm{dt}_{\max }$ and ventilation; also the $\mathrm{FEV}_{1}$ was unchanged. Although the $\mathrm{CO}_{2}$ feedback control circuit is partly modulated by peripheral chemoreceptors that are under sympathetic control, ${ }^{19}$ the medullary chemoreceptor is probably of major importance. ${ }^{16} 20$ Our experiments were performed under hyperoxic conditions, which wouid reduce the peripheral component of the $\mathrm{CO}_{2}$ response, ${ }^{21}$ and in view of the magnitude of changes it is likely that propranolol was acting centrally.

Propranolol has been identified in human brain tissue ${ }^{22}$ and may produce central nervous system side effects such as nightmares and hallucinations. A central action was proposed in a study of essential tremor. ${ }^{23}$ Central action has also been postulated on the basis of hypotension after the intracerebroventricular injection of the drug in hypertensive rabbits, ${ }^{24}$ but so far there has been little convincing evidence for a pharmacological action on the vital centres in man.

Our findings suggest that propranolol has a central action after oral doses of only $80 \mathrm{mg}$. This property may not be common to all beta-blocking drugs since their ability to enter the central nervous system varies greatly; current studies are investigating this further.

Although some workers ${ }^{25}{ }^{26}$ have claimed that propranolol is safe in patients with chronic bronchitis our results suggest that caution should be exercised in treating such patients, who may be at risk from respiratory depression, particularly during sleep.

We thank Profesor J B L Howell for advice, Dr M Castleden for performing the plasma assays, and Miss L Henry for technical help. CPM is supported by a Prophit Scholarship of the Royal College of Physicians. HRG is in receipt of a Burroughs Wellcome grant. ICI kindly supplied the $\mathrm{D}$-propranolol. 


\section{References}

${ }^{1}$ Langer, I, fournal of Physiology, 1967, 190, 41P.

${ }^{2}$ Beumer, H M, Lancet, 1967, 2, 993.

${ }^{3}$ McNeil, R S, Lancet, 1964, 2, 1101.

4 Whelan, R F, and Young, I M, British fournal of Pharmacology, 1953, 8, 98.

5 Young, I M, fournal of Physiology, 1957, 137, 374.

${ }^{6}$ Lambertsen, C J, in Handbook of Physiology, section 3, vol 1, ed W O Fenn and H Rahn, p 551. Washington, American Physiological Society, 1964.

7 Leitch, A G, et al, British Medical fournal, 1976, 1, 365.

${ }^{8}$ Rebuck, A S, Jones, N L, and Campbell, E J M, Clinical Science, 1972, 43, 861 .

${ }^{9}$ Matthews, A W, and Howell, J B L, Clinical Science and Molecular Medicine, 1975, 49, 57.

${ }^{10}$ McNeil, R S, and Ingram, C G, American fournal of Cardiology, 1966, $18,473$.

${ }^{11}$ Macdonald, A G, Ingram, C G, and McNeill, R S, British fournal of Anaesthesia, 1967, 39, 919.

12 Richardson, P S, and Sterling, G M, British Medical fournal, 1969, 3, 143.
13 Tattersfield, A E, Leaver, D G, and Pride, N B, fournal of Applied Physiology, 1973, 35, 613.

14 Gayrard, P, et al, Thorax, 1975, 30, 657.

15 Barrett, A M, and Cullum, V A, British fournal of Pharmacology, 1968, 34, 43.

${ }^{16}$ Read, D J C, Australasian Annals of Medicine, 1967, 16, 20.

17 Shand, D G, Nickolls, E M, and Oates, J A, Clinical Pharmacology and Therapeutics, 1970, 2, 112.

${ }^{18}$ Matthews, A W, and Howell, J B L, Clinical Science and Molecular Medicine, 1976, 50, 199.

19 Purves, M J, and Biscoe, T J, in Arterial Chemoreceptors, ed P W Torrance. Oxford, Blackwell, 1968 .

${ }^{20}$ Read, D J C, and Leigh, J, Fournal of Applied Physiology, 1967, 23, 53.

${ }^{21}$ Lefrancois, R, et al, Respiration Physiology, 1972, 14, 296.

${ }^{22}$ Myers, M G, et al, fournal of Pharmacology and Experimental Therapeutics, 1975, 192, 327.

${ }^{23}$ Young, R, Growdon, J H, and Shahani, B T, New England fournal of Medicine, 1975, 293, 950.

${ }^{24}$ Bakke, O M, et al, British fournal of Pharmacology, 1974, 51, $148 \mathrm{P}$.

${ }^{25}$ Stone, D J, Kelts, H, and Samortin, T, American Review of Respiratory Disease, 1971, 103, 503.

${ }^{26}$ Nordstrom, L A, Macdonald, F, and Gobel, F L, Chest, 1975, 67, 287.

\section{SHORT REPORTS}

\section{Persistent intestinal protein loss after measles}

Measles is one of the commonest precipitating factors in kwashiorkor. ${ }^{1}$ There is appreciable intestinal protein loss during acute measles infection in underweight children with diarrhoea, ${ }^{23}$ and $I$ have investigated the possibility that if this persists it might cause kwashiorkor.

\section{Patients, methods, and results}

Six children with persistent diarrhoea after measles were studied. The history of measles was confirmed either by documentation during the acute illness or by post-measles skin staining on examination. None had diarrhoea before the onset of measles. Their ages ranged from 20 months to 9 years (mean age 38 months). All weighed less than $80 \%$ of the Harvard standard growth curve (mean value $59+\mathrm{SD} 10 \%$ ). Their mean serum albumin level was $23 \pm 4 \mathrm{~g} / \mathrm{l}$. Three of the children had developed oedema since the acute illness. Stool culture grew no important pathogens. One child had ova of Schistosoma mansoni in the stool. Controls were five children who had recovered from measles but were being reinvestigated after intestinal protein loss had been found during acute measles, as described previously. ${ }^{2}$ Their mean age was $30 \pm 13$ months, and their mean weight $81 \pm 15 \%$ of the Harvard standard growth curve.

${ }^{59} \mathrm{FE}$-labelled iron dextran $\left({ }^{59} \mathrm{FE}\right)$ was used to measure intestinal protein loss. A dose of $0.1 \mu \mathrm{Ci} / \mathrm{kg}$ was injected intravenously, and all stools over the next three days were collected. Plasma was sampled daily. The faecal clearance of ${ }^{5 y} \mathrm{FE}$ thus calculated correlated closely with plasma protein loss into the gut. ${ }^{4}$ With the assumption that albumin is cleared similarly to ${ }^{59} \mathrm{FE},{ }^{4}$ the absolute albumin loss was estimated from the faecal ${ }^{59} \mathrm{FE}$ clearance and calculated total intravascular albumin pool. The mean faecal clearance in the patients with post-measles diarrhoea was $6.5 \pm 4.2 \%$ of the plasma volume daily. This was significantly higher than in the controls, whose clearance was $2.0 \pm 0.9 \%$ of the plasma volume daily $(t=2.6 ; \mathrm{P}<0.05)$. Those with oedema had a greater clearance than those without oedema (see figure). The mean absolute albumin loss was significantly $(P<0.05)$ greater in the patients with post-measles diarrhoea $(0 \cdot 9 \pm 0.7 \mathrm{~g} /$ day $)$ than in the controls $(0.4 \pm 0.3 \mathrm{~g} /$ day $)$.

\section{Discussion}

The patients with post-measles diarrhoea continued to lose protein in the stool two to four weeks after measles, having a similar ${ }^{59} \mathrm{FE}$ clearance to that found in acute measles ${ }^{2}$ and a significantly higher clearance than children who had recovered from measles.

Kwashiorkor developed in the three patients with the highest protein losses. The mean absolute albumin loss in all the patients with post-measles diarrhoea was almost $1 \mathrm{~g}$ daily-an important loss, since their mean total intravascular albumin pool was only $13 \pm 4 \mathrm{~g}$. The mean loss of $0.4 \mathrm{~g}$ albumin daily in the controls was from a mean total intravascular albumin pool of $24 \pm 7 \mathrm{~g}$. Shukry et $a l^{5}$ found that children with kwaskiorkor lost little protein in the stool in the absence

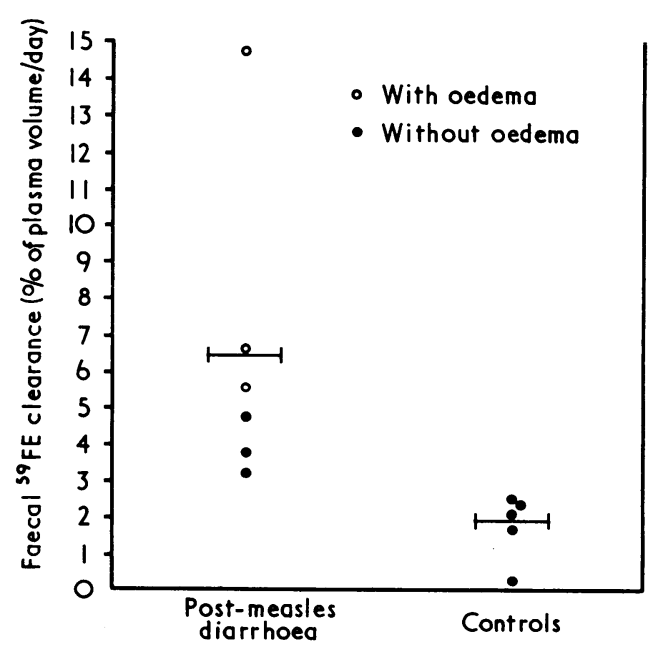

Clearance of ${ }^{59} \mathrm{FE}$-labelled iron dextran in six patients with post-measles diarrhoea and five controls $(t=2 \cdot 6$; $\mathbf{P}<0.05)$.

of diarrhoea, and our unpublished results confirm this. Thus the protein loss in the patients with post-measles diarrhoea was related to the diarrhoea and not to the poor state of nutrition.

We do not know whether measles virus has any specific role in the syndrome of post-measles diarrhoea. Superinfection by bacteria or fungi in the large bowel or small bowel is a possible explanation, since secondary infections after measles are common in other tissues. Possibly underweight children with diarrhoea from any cause may lose similar amounts of protein to the children in this study.

I thank Dr Norman Veall for the ${ }^{59} \mathrm{FE}$-labelled iron dextran, and Dr $\mathrm{H}$ Whittle and Dr B M Greenwood for their help.

${ }_{1}^{1}$ Ogbeide, M I, West African Medical fournal, 1971, 20, 313.

2 Dossetor, J F B, and Whittle, H C, British Medical fournal, 1975, 2, 592.

3 Axton, J H M, British Medical fournal, 1975, 3, 79.

${ }^{4}$ Jarnum, S, et al, Gastroenterology, 1968, 55, 229.

5 Shukry, A S, et al, fournal of Tropical Medicine and Hygiene, 1965, 68, 269.

Department of Paediatrics, Ahmadu Bello University, Zaria, Nigeria

J F B DOSSETOR, DCH, MRCP, lecturer in paediatrics 